\title{
Social History in Norway in the 1970s and Beyond: Evolution and Professionalisation
}

\author{
Jan Eivind Myhre \\ Department of Archeology, Conservation and History, University of Oslo, Niels Henrik Abels vei 36, Niels Treschows \\ hus, 0851, Oslo, Norway \\ j.e.myhre@iakh.uio.no
}

The rise of the new social history ('sosialhistorie' in Norwegian) in Norway from around 1970 was more of an evolution than a revolution. The social aspect of Norwegian history writing had been important for decades, a trait which also may explain its success. What was unusual, however, was the conscious application of new terms, theories and methods, partly borrowed from the social sciences, and the introduction of 'social history' as a rallying point. This article tries to show that processes of professionalisation - characterised by specialisation and with increasing emphasis on originality - were an important element of this new social history.

In a lecture in 1964 the prominent Norwegian historian Andreas Holmsen (1906-89) commented on the state of the country's historiography. Holmsen was a historian of the Middle Ages and the Early Modern period, known for his structural approach to economic and settlement history, not unlike what was published in the Annales at the time. In the lecture he compared his way of doing history with that of another prominent historian, his contemporary and adversary Jens Arup Seip (1905-92). Seip was trained as a historian of the Middle Ages, but later turned to studying the nineteenth century. Previously sympathetic to the social sciences, he had turned against it (at least as an inspiration to history), and now favoured studying political history and the struggle for power. ${ }^{1}$ In the 1960s Holmsen thought Seip to be by far the most influential of the two, or indeed compared to anyone, in the Norwegian history discipline. Political history was dominant. Seip had won, Holmsen wrote, and he had lost. ${ }^{2}$

Only a few years later, the tables had turned. From the early 1970s, social history - also known as the 'new social history' or simply the 'new history' - was on nearly everybody's lips. ${ }^{3}$ Books, articles, $\mathrm{PhD}$ theses and master's dissertations poured out, many declaring explicitly their genre as 'social history', which was the preferred term in Norway. ${ }^{4}$ Interestingly, the chronological centre of attention was the century of Seip's research, the nineteenth, with its far-reaching social changes. Perhaps equally interesting was Seip's own reaction. He found much of the new work on

\footnotetext{
1 Jens Arup Seip, Problemer og metode i historieforskningen (Oslo: Gyldendal, 1983). See also Jan Eivind Myhre, 'Historikeren og sosiologen: en nærvøs romanse', Nytt norsk tidsskrift, 4 (1999).

2 Holmsen's lecture was printed in 1966. Andreas Holmsen, 'Menneske, mønster og masse i historien, Historisk tidsskrift (1966), 330-9. All translations from the Norwegian by the author.

3 This new kind of history, characterised by topics as well as methods, has many names. One may, for example, speak of the 'new economic history'. See Peter Burke, ed., New Perspectives in Historical Writing (Cambridge: Cambridge University Press, 1991) and Jan Eivind Myhre 'Unification in the Age of Fragmentation', in Jan Eivind Myhre, ed., Boundaries of History (Oslo: Scandinavian Academic Press, 2015), 25-54. I will throughout use the term 'the new social history' to characterise the new tendencies from around 1960 onwards (there was an older social history).

4 The Master's dissertation was called «hovedfagsoppgave» (main thesis). They were substantial contributions, often running to $200-300$ pages, sometimes published as books.
} 
social history fruitful and even incorporated some of it in his masterly overview of late nineteenth-century Norwegian history, published in $1981 .^{5}$

The surge of new social history was, by and large, well received in Norway by the younger as well as the older generation of historians. This reaction may be contrasted to other countries like the United States, Britain or Germany - where adherents to the 'old' history put up a fight. ${ }^{6}$ The young Norwegian historians did not 'defer to the elders of the tribe', as one of Tony Becher's informants told him, nor did the Norwegian elders show a condescending attitude. ${ }^{7}$ To explain this peculiarity, it is important to understand that the impetus for a Norwegian new social history came from within and from outside. It drew on both local and foreign influences, including from the United States, Britain, Germany, France and the rest of Scandinavia. But we should still ask the question: what was the new social history about? Was it inundated with methods and theories from the burgeoning social sciences? Was it a political project where the oppressed in history were given a voice as well as ammunition for creating a better future? Or was it an epistemic revolution, a fundamentally new concept of what history is all about?

\section{The New Social History in Norway: Three Generations}

There are good arguments in favour of the thesis that the new social history, the introduction of which in Norway we may date to about 1970, built on previous innovations. It met with little resistance because there was an inheritance to build on. It was, in fact, never referred to as the 'new' social history at all.

There were, to begin with, the grandfathers of social history, avant la lettre. The writings of Halvdan Koht (1873-1965) and Edvard Bull the elder (1881-1932) paved the way for a broad conception of what history was about. There was a tradition from the interwar years onwards of doing agricultural history and settlement history with the peasant or farmer as a pivotal figure. Asgaut Steinnes, Sigvald Hasund, Arne Odd Johnsen and Andreas Holmsen were crucial names. Johan Schreiner and Wilhelm Keilhau widened the field to other areas. The towering figure, the great narrator in Norwegian historiography, was Sverre Steen (1898-1983), with his sweeping descriptions of Norwegian society from the sixteenth to the twentieth centuries. His book on preindustrial Norwegian society in the first half of the nineteenth century, The Old Society (Det gamle samfunn) became required reading for later social historians. ${ }^{8}$ The reasons for the interest in this kind of social history were not hard to find. While national identity in many countries (like Sweden) lay with the stories of kings and warriors, in Norway it lay with its people since the country for many centuries was ruled by foreign masters. The continuity in Norwegian history could be found in its peasants, not its dynasties. ${ }^{9}$

Alongside the grandparents of social history, there were aunts and uncles. Ingrid Semmingsen's two volumes about emigration to the United States, Knut Mykland's history of the city of Trondheim in the nineteenth century, Dagfinn Mannsåker's thesis on the recruitment to the Norwegian clergy and the writings of the methodologist and historiographer Ottar Dahl in the 1940 s and 1950s were some of the hallmarks. Mannsåker and (especially) Dahl were also

\footnotetext{
5 Jens Arup Seip, Utsikt over Norges historie, vol II 1851-1884 (Oslo: Gyldendal, 1981).

${ }^{6}$ Gertrude Himmelfarb, The New History and the Old (Cambridge, Mass, The Belkanp Press of Harvard University Press 1987); Jan Eivind Myhre, 'Social History', in William H. Hubbard, Jan Eivind Myhre, Trond Nordby and Sølvi Sogner, eds., Making a Historical Culture. Historiography in Norway (Oslo: Scandinavian University Press, 1995).

7 Becher studied Great Britain and the United States. Tony Becher, Academic Tribes and Territories. Intellectual Enquiry and the Culture of Disciplines (Buckingham: The Society for Research into Higher Education \& Open University Press, 1989), 60.

8 Sverre Steen, Det gamle samfunn (Oslo: Cappelen, 1957). See also Myhre, 'Social History'.

9 From an independent kingdom during the Middle Ages, Norway went into union with Denmark, in a clearly subordinate position, lasting until 1814. In the personal union with Sweden 1814-1905, Norway had its own institutions, while the king was Swedish.
} 
theoretically well informed. They were also the first to employ the term 'social history' - Mannsåker in the subtitle of his book, Dahl in the title of his review of the book. Dahl's theoretical article 'Some Theoretical Problems in Social History' (Noen teoretiske problemer i sosialhistorien) from 1955 became a starting point for future social historians. Social history, he stated, 'will attempt to treat all relevant aspect of human social life in context, and especially the way it manifests itself in larger units or 'social groups' and in their mutual relationship'. ${ }^{10}$ Not least, there was Edvard Bull the younger (1914-86), pleading in the 1950s for a history of common people, workers in particular.

Despite the strength of a history of society in Norway, political history still constituted the backbone of post-war Norwegian historiography, even strengthening its position in the 1960s. The influence of Seip was strongly felt. His students Alf Kaartvedt and Rolf Danielsen, then professors at the University of Bergen, wrote the history of the Norwegian parliament for its $150^{\text {th }}$ anniversary in 1964. Of Sverre Steen's seven volumes of Norwegian history in the decades following (semi-)independence, six dealt mainly with political history. Moreover, Bull the younger and Sivert Langholm (born 1927, another social history pioneer) kept quiet about social history in the sixties. Bull's book from 1958 on industrial workers during the industrial breakthrough received modest attention until the 1970 s, when it was reprinted twice. ${ }^{11}$ In an anthology from 1970 commemorating the first hundred years of Historisk tidsskrift, Steen and Semmingsen were represented by articles on political history. ${ }^{12}$ After having published a book on the creation of the Norwegian industrial working class in 1958 (another starting point for the young new social historians), Bull turned to African history, and Langholm wrote a thesis within political history with Seip as his supervisor. This was the background for Holmsen's lament: 'it is political history - the history of political thoughts and actions - which is the subject of historians harbouring full self-respect'. ${ }^{13}$ A change, however, was on its way.

In 1970 the Norwegian Historical Association held its 100th anniversary conference, which featured keynote talks by Seip, Bull and Langholm on the future of the history discipline. ${ }^{14}$ Seip pleaded for political history as the central element in the discipline, arguing that politics was the key to the wider historical experience and that laws, adopted by politicians, governed society as a whole. Tellingly, he called Norwegian society during most of the nineteenth century a 'civil servant state' (embetsmannsstaten), named after its ruling class. Bull, in his contribution to Seip's Festschrift, characterised Norwegian nineteenth-century history with the phrase 'from a society of peasants and crofters to one of organised capitalism', thereby focusing on the social aspect of history. ${ }^{15}$

By contrast, Bull and Langholm's keynote interventions went in another direction, with aims and projects that would later earn them the title of the 'fathers' of the new social history. ${ }^{16}$ Bull taught at the University of Trondheim (present-day Norwegian University of Science and Technology), basing much of his and his students' research on the large collection of worker's memories, collected by him and collaborators at the Norwegian Folk Museum in Oslo in the 1950s. While Bull was somewhat sceptical towards the uses of social science in history, especially its quantitative side, his colleague in Oslo, Sivert Langholm, was certainly not. His article 'The

\footnotetext{
10 Dagfinn Mannsåker, Det norske presteskapet i det 19. hundreåret (Oslo: Universitetsforlaget, 1954); Ottar Dahl, 'Noen teoretiske problemer i sosialhistorien', Historisk tidsskrift (1955), 185-203.

11 Edvard Bull, Arbeidermiljø under det industrielle gjennombrudd (Oslo: Tiden, 1958).

12 Hundre års historisk forskning (Oslo, Universitetsforlaget, 1970). It should be added that Dahl's article on social history was included, together with a social historical article by Bull the younger.

13 Holmsen, 'Menneske, mønster og masse', 331, 337.

14 Historisk tidsskrift, 1970. Seip's contribution was already written in 1967.

15 Edvard Bull, 'Fra bøndenes og husmennenes samfunn til den organiserte kapitalisme', in Ottar Dahl et al, eds., Makt og motiv. Et festskrift til Jens Arup Seip (Oslo: Gyldendal, 1975).

16 This designation is the author's, in the firm belief that most Norwegian historians would agree.
} 
Historian and the Sociologist - and the Third Man' stated that his ideal was the latter, not the historian or sociologist only, but both at the same time. ${ }^{17}$

With Dahl, and aided by Semmingsen, in the early 1970s Langholm launched a large research project - The Development of Norwegian Society c. 1860-1900 - mobilising dozens of graduate students for more than a decade. ${ }^{18}$ 'Social history' became a clarion call for these students, the term figuring in numerous dissertation subtitles. ${ }^{19}$ This applied to all four universities and the numerous colleges established in the 1970s, whose lecturers were mainly recruited from the first generation of new social historians. The number of social history dissertations (hovedfag) rose from about five annually to almost thirty in the peak years of 1974-83, making up about 40 per cent of all dissertations in the early eighties. Between 1976 and 1979 the publisher Cappelen produced a fifteen-volume general history of Norway under the editorship of Knut Mykland. The task at hand was 'writing history as a history of society in the widest sense of the word', with population, social structure and culture figuring prominently. It was a solid manifestation of the historiographical tendencies of the seventies. ${ }^{20}$

\section{What Kind of Social History?}

The new social history in Norway was in many ways a journey into the unexplored, with the aim of filling in blind spots on the historiographical map. Despite what had been done by previous historians, there was much land to discover and unveil. Not least, young historians (and they were mainly young) had new theories and methods at their disposal. In addition, the political climate in the late sixties and seventies was favourable for historians who wanted to look at history with new eyes. In many cases, Norway's new social historians were exploring the domestic past with maps and compasses borrowed from abroad.

They were also aided in their work by various institutions, like archives and collections of memories from older people of all strands in society. The archive and library of the labour movement was founded in 1908, adding to the treasuries to be found in the older national, regional and local archives as well as private ones, all of them employed in a different way than previously, as topics about politics and administration gave way to newer questions of a social historical kind. After the Second World War historians, ethnologists and folklorists established collections of memories, by interview or written down by people themselves. The increasing interest in local history added to the rise of social history.

Social history - sosialhistorie - in Norway is a term covering a variety of periods, themes, approaches, theories and methods. Yet it is possible to single out common traits, some of them imported, some domestic. First, graduates and post-graduates wanted to study social groups, following Dahl's definition above, meaning an emphasis on social structure. This meant moving away from histories of prominent individuals or the writing of biographies. Instead, publications covered groups like manufacturing workers, craftsmen, domestic workers, prostitutes, immigrants, crofters, industrial entrepreneurs, demographic cohorts, telegraphers and prison inmates. This was, with some exceptions, history from below. ${ }^{21}$ Or, as Bull put it, a history of 'people

17 Sivert Langholm, 'The Historian, the Sociologist - and the Third Man, Historisk tidskrift (Sweden), 4 (1972), 474-89. The article was based on a presentation at an international conference, so its appearance in a Swedish journal is accidental.

18 Sivert Langholm, 'Historie på individnivå. Omkring Ullensaker-undersøkelsen - et mikrohistorisk eksperiment', Historisk tidsskrift, 3 (1974), 243-72; Sivert Langholm, 'On the Scope of Micro-History', Scandinavian Journal of History, 1 (1976), 1-24. The project also went under the name of the Ullensaker and Christiania projects, named after the localities studied.

19 On the 'hovedfag' theses, see note 4 above.

20 Knut Mykland, 'Om å skrive norgeshistorie', Knut Mykland, ed., Norges historie, vol 1 (Oslo: Cappelen, 1976), 5-10.

21 The Festschrift to Bull on his seventieth birthday in 1984 was aptly titled Historie nedenfra, history from below. Per Fuglum and Jarle Simensen, Historie nedenfra. Festskrift til Edvard Bull på 70-årsdagen (Oslo: Universitetsforlaget, 1984). A collection of Bull's articles was named Retten til en fortid, The Right to a Past, Subtitled Essays on Social History. Edvard Bull, Retten til en fortid. Sosialhistoriske artikler (Oslo: Universitetsforlaget, 1981). 
without power'. The term 'history from below' (historie nedenfra) was, of course, borrowed from abroad. By accident, one student named it 'history with the bottom up' (in English), foreshadowing later writings on sexual behaviour. The new role attached to gender was, however, visible from early on in the emphasis on female telegraphers, workers, prostitutes, domestic workers, crofters and peasants/farmers. While the men in agriculture and fishing were away as fishermen, lumberjacks or construction workers, the women were the true farmers, especially along the coast.

Some of the work concentrated on collectives like the socialist organisation named after its leader, Marcus Thrane (c. 1850), the early workers' societies (Christiania Arbeidersamfund), or the female domestic workers' union. Generally, historians emphasised social recruitment to these collectives and the mutual connection between their members. But these organisations were also political actors, and the new social historians saw no reason to put up a barrier between the social and the political. Seip remarked about Tore Pryser's book on a local branch of the Thrane movement, a social historical flagship which contained a tremendous collective biography of all its 173 members, that it was really a work about political behaviour. ${ }^{22}$ In this sense, Langholm's launching of a social historical approach around 1970 was not directed against political history as such, but against the one-sidedness of Norwegian historiography at the time. ${ }^{23}$

The overarching theme for the new social historians of the 1970s was the great social transformation of the long nineteenth century. This incorporated processes such as industrialisation, urbanisation and emigration. Historical demographers stuck mainly to the eighteenth and early nineteenth centuries, and some work was done on the early twentieth century. Social history, as a matter of fact, cut across traditional periodisation of history, as social and economic processes did not coincide well with political ones. This is especially true for the many studies of 'the big change' (det store hamskiftet), the important technological and social shift in agriculture that made peasants into farmers.

Langholm called his vision of social history 'micro history'. ${ }^{24}$ This should not be confused with the continental (or Italian) brand of microhistory, which was a close-grained study of social phenomena. ${ }^{25}$ Rather, Langholm conceived of micro history as a methodological device, the main point of which was to combine properties in the individual, among other things to avoid ecological fallacies. It was not enough to explain, for instance, emigration by referring to general social or economic circumstances. The historian had to connect variables on the individual level. The method, then, was akin to collective biography (or prosopography, as Lawrence Stone called it), and meant bringing individuals back into an otherwise rather structural kind of history.

As the fascination for social history faded, historiographers began to analyse the social history boom in the 1970s (and partly the 1980s), and especially the differences between the two main milieus, Langholm's group in Oslo and Bull's in Trondheim. ${ }^{26}$ Langholm's students were more inclined towards structural approach (often inspired by sociology). They focused on social groups, employed statistical methods and contributed to the larger societal picture. In this respect, their approach resembled that of the German history and society (Geschichte und

\footnotetext{
22 Tore Pryser, Klassebevegelse eller folkebevegelse? En sosialhistorisk undersøkelse av thranittene i Ullensaker (Oslo: Universitetsforlaget, 1977).

${ }^{23}$ Knut Kjeldstadli and Jan Eivind Myhre, 'En bundet lidenskap. Samtale med Sivert Langholm om historiefaget', in Knut Kjeldstadli, Jan Eivind Myhre and Tore Pryser, eds., Valg og vitenskap. Festskrift til Sivert Langholm (Oslo: Den Norske Historiske Forening, 1997), 9-36.

24 Langholm, 'Historie på individnivå’; Langholm, 'On the Scope of Micro-History'.

25 Giovanni Levi, ‘On Microhistory', Burke, New Perspectives, 93-113.

26 Dagfinn Slettan, 'Sosialhistorie etter 1970. "Fra sosialhistorie til kulturhistorie”, Historisk tidsskrift, 1/2 (1996), 78-116; Dagfinn Slettan, 'Å åpne dører - Edvard Bull og sosialhistorien’, in Anne Kristine Børresen, Jan Eivind Myhre and Ola Svein Stugu, eds., Historikerne som historie (Trondheim: Historisk institutt, 1996), 73-91; Finn Olstad, 'Sosialhistorien etter Langholm’, in A. K. Børresen et al, eds., 93-105; Ingar Kaldal, Frå sosialhistorie til nyare kulturhistorie (Oslo: Samlaget, 2002).
} 
Gesellschaft) school, but before the journal of that name saw the light of day in 1975. Bull's students, on the other hand, were more oriented towards everyday life, anthropology and narrative style. This must not conceal what the two groups had in common: history from below, an interest in classes, local studies and the expansion of the scope of history.

Doing history from below, gender history (or women's history, as it was called in the seventies) and investigating the actions of industrial entrepreneurs also had a political side to it. With the possible exception of gender/women's history, the element of identity politics was not very strong, unlike, say, in the United States. The main argument in favour of women's history, on par with a number of other groups in society, was making visible hitherto neglected groups and underlining their contribution to history. ${ }^{27}$ Nevertheless, Norway had its own version of the New Left, and many young aspiring historians were part of it, being politically active as well as doing research on ignored groups. ${ }^{28}$ In 2010 Tor Egil Førland, a representative of a younger generation of historians (b. 1959), claimed that politics skewed the perspective of the 1970s generation (or '68ers, as they are sometimes called) and made their research too partisan and too politicised. ${ }^{29}$ But, while the choice of topics in this period was obviously made for political or social reasons, the content of research was clearly not, as it was guided by rather strict methodological rules, overseen by Bull, Langholm, Dahl and others. In any case, one could easily argue that historians always choose their topics for political reasons, or based on values in a more general sense.

Although the main label for the new history in the seventies was social history, other subdisciplines were part of the larger picture, sometimes subsuming themselves under the social history umbrella. Historical demography was one such sub-discipline. Economic history and business history were half-sisters of social history. Local and urban histories, both time-honoured branches of academic history, got a social-historical bent in the 1970s. The sub-disciplines often had their own conferences or workshops, although in a small country like Norway they did not create their own specialised journals. The exception was local history and its journal Heimen, founded already in 1922. Women's history started out more or less as a branch of social history, focusing on the neglect of women's role and contribution in history, explicitly taking its cue from the emerging women's liberation movement. It soon found its own way, led by towering figures like Ida Blom (1931-2016) and Gro Hagemann (b. 1945). It came to comprise virtually all sides of the female experience, from wives and mothers to breadwinners, from victims to agents, from politics to demography. ${ }^{30}$

\section{Inspiration}

Although the new social history in Norway had its domestic predecessors, much of its inspiration came from abroad. Bull and Koht looked to Leipzig and Karl Lamprecht's wide cultural history, and Bull wrote Lamprecht's obituary in 1915. ${ }^{31}$ The Institute of Comparative Cultural History in Oslo invited Marc Bloch and Alfons Dopsch in the late 1920s, and Bloch's work, which later became French Rural History, began there. ${ }^{32}$ Some of Holmsen's work resembled Annales history,

27 The history of the indigenous minority in the north, the Sami, as well as other ethnic minorities, came somewhat later.

28 Sivert Langholm, 'Forord', in Jan Eivind Myhre and Jan Sigurd Østberg, eds., Mennesker i Kristiania. Sosialhistorisk søkelys på 1800-tallet (Oslo: Universitetsforlaget, 1979), 7-10.

29 Tor Egil Førland, 'Deltaker og medløper. Venstresiden, sovjetunionen og objektivismens fall', Historisk tidsskrift 4 (2010), 521-46.

30 Ida Blom, 'Women's History', in Hubbard, Myhre, Nordby and Sogner, eds., Making a Historical Culture, 289-310.

31 Edvard Bull the elder, 'Professor Karl Lamprecht', Tidens tegn (newspaper), 16 May 1915. Johan Schreiner, ed., Historie og politikk (Oslo: Tiden, 1933), 16-9.

32 Jon Røyne Kyllingstad, 'Nationalist Internationalism: Danish and Norwegian Historical Research in the Aftermath of the First World War', in Pertti Haapala, Marja Jalava and Simon Larsson, eds., Making Nordic Historiography (New York: Berghahn, 2017), 173-6. 
although he denied direct influence. Mykland's city history from the fifties was devoid of explicit international references, but he later admitted that the Lynds' Middletown studies had been an inspiration. And Mannsåker and Dahl were well aware of contemporary sociological theory.

It was the same story for the new social historians of the 1970s. Even as late as the mid-sixties, social science and history were far apart, but, by the seventies, it had become commonplace for history students to study social science, and, to some degree, vice versa. ${ }^{33}$ Students were well versed in social scientific theory and methods, derived largely from political science, human geography, ethnology and economics. Social anthropology came later, literature later still, and psychology was never important for Norwegian historians. Norwegian social scientists had some influence, like the political scientist Stein Rokkan's concepts of centre and periphery in Norwegian history. The Marxist influence was quite strong, but seldom in a dogmatic fashion, rather in a materialistic version. The German tradition of Weber, Tönnies and others was present since this was a body of theory especially suited to Norwegian historians' main goal of describing and analysing industrialising society. The influence of the German Bielefelder School was to some degree present, as its notion of Gesellschaftgeschichte suited the Norwegian case. Then there was the importance of American sociology, which was strongly felt in the first decades after the Second World War. The similarities between the United States and Norway were perhaps greater than first meet the eye. Both countries lacked a feudal past and there was no nobility. The independent peasant/farmer was for a long time the backbone of society in both countries, and the Norwegian constitution of 1814 was based on the US one. Both countries had frontiers in the nineteenth century.

On the level of individual scholars, however, some British historians stood out as particularly influential. Eric Hobsbawm was an obvious choice as a model, not least his article 'From Social History to the History of Society'. A Norwegian twist on this was titled 'From the History of Society to Social History', referring to the older social history tradition and the new social history from around $1970 .{ }^{34}$ Another model was E. P. Thompson because of the many attempts at delineating the rise of the Norwegian working class. However, Norwegian historians, unlike their British Marxist counterparts, did not discern a fall in the living standards during the first phase of industrialisation. The historical demographers of the Cambridge school were certainly important to their (relatively) few Norwegian colleagues, but French demographers, inventing the discipline, were just as influential. The influence of the Annales came only in the eighties, in the shape of the history of méntalités. In the Oslo milieu in particular, Harold Perkin was held in high esteem because of his articles defining the field of social history and his overview of English nineteenth-century history. ${ }^{35}$ His concepts of 'estate society' and 'class society' became canonical concepts among younger Norwegian social historians (standssamfunn and klassesamfunn).

The rise of the new social history also precipitated a convergence between Scandinavian countries. Nordic history conferences started already in 1905, but of particular relevance to social history were the special conferences on theory and methods taking place annually between 1965 and 1989. ${ }^{36}$ Nordic (or Scandinavian) history journals were founded in this period, too. ${ }^{37}$ Although the older Swedish history tradition was mainly one of kings, wars and politics, a major

\footnotetext{
33 Students had to study three subjects for their undergraduate degree. See Jan Eivind Myhre, 'Historikeren og sosiologen: en nervøs romanse?', Nytt norsk tidsskrift, 4 (1999), 321-35.

34 Eric Hobsbawm, 'From Social History to the History of Society', in Felix Gilbert and Stephen Graubard, eds., Historical Studies Today (New York: Norton, 1972), 1-26; Jan Eivind Myhre, 'From the History of Society to Social History', Jahrbuch für Wirtschaftsgeschichte, 1 (1996), 259-78.

35 Harold Perkin, The Origins of Modern English Society 1780-1880 (London: Routledge, 1969). Some of Perkin's essays, among them the influential 'What is Social History', are collected in The Structured Crowd. Essays in English Social History (Sussex: The Harvester Press, 1981).

36 Jarle Simensen, 'The Nordic Historians' Conferences on Historical Method, 1965-1989', in Jarle Simensen, Internasjonalisering $i$ historiefaget. Global historie og norsk historie i transnasjonalt perspektiv (Oslo: Unipub, 2008), 49-64.

37 Scandia (1928), Scandinavian Economic History Review (1954) and Journal of Scandinavian History (1976).
} 
social historical thrust took place from 1970 onwards, no doubt influenced by the rise of the welfare state. In any case, Nordic historians, not least social historians, learned a lot from each other. Norwegian social historians, as well as other historians, reached further out from the seventies onwards, participating in European and US conferences, staying as guest researchers abroad and publishing in international journals and books. But, even without this participation, international influence was highly visible (in texts, footnotes and literature list), even when the publications in question were about Norwegian history.

As will be clear by now, social history was not met by any fierce resistance within the Norwegian historical community, mainly due to the time-honoured tradition of writing people's history. Social history's left-wing tendency caused little stir, as the history profession was rather left leaning in the first place, even if the Marxist-Leninists ( $m$-l-erne, the $\mathrm{m}$-ls, in Norwegian usage) preferred political history. Nevertheless, some critics did emerge quite late in the 1990s. Their criticisms were not against social history as such, but against what they saw as its dominance, reversing the situation from a generation earlier. ${ }^{38}$ It is worth discussing some of these criticisms here.

In 1984 Per Maurseth (1932-2013), a historian of political history, accused social historians of isolating social history - or the 'social' in history - as an explanatory framework. ${ }^{39}$ The critique had some substance, but was mainly misplaced. Francis Sejersted's (1936-2016) objection was more on target. He argued that social history failed to give history meaning because it concentrated too much on unplanned consequences of uncoordinated mass behaviour and treated people too much as victims. Sejersted recommended placing renewed emphasis on institutions, particularly political ones. I would argue that such a critique overlooks the fact there is a wide variety of social institutions created by people to provide their lives with meaning. A younger historian, May-Brith Ohman Nielsen (b. 1962) adopted a different angle of attack and suggested that social historians' preoccupation with 'unopened boxes', like penitentiaries, barns and factory halls, lacked any connection to larger problems and themes. ${ }^{40}$ In a similar vein, Erik Opsahl (b. 1960) reacted against what he saw as a one-sided emphasis on the lower classes, wanting to investigate the social characteristics of the nobility in the later Middle Ages. ${ }^{41}$

'Today', the historian Ingar Kaldal (b. 1955) wrote in 2002, 'it hardly causes a stir, and hardly any resistance, to claim that the great epoch of social history is over'. ${ }^{2}$ This diagnosis was to be heard many times from the late 1980s onwards, from both Kaldal and his fellow historians Dagfinn Slettan (1941-99) and Finn Olstad (b. 1950), as well as some younger historians. ${ }^{43}$ But this was not a call for political history; it was a call for a new cultural history, inspired by anthropology and linguistics. For the three authors, cultural history was not so much a break with social history as a continuation of it. As we can see in the writings of Knut Kjeldstadli (b. 1948), the two became intertwined. ${ }^{44}$

38 This appears to be a bit exaggerated.

39 Per Maurseth, 'Mellom Seip og Bull. Tilbakeblikk på en jubileumsdebatt, in Fuglum and Simensen, Historie nedenfra, 138-49.

40 May-Brith Ohman Nielsen, 'Framtid for den faglige frimodigheten', HiFo-nytt, 3 (1995); Jan Eivind Myhre, 'Unification in the Age of Fragmentation. The Aims of the New History', in Jan Eivind Myhre, ed., Boundaries of History (Oslo: Scandinavia Academic Press, 2015), 25-54.

41 Erik Opsahl, 'Historiens mangfold', in Anne Kristine Børresen, Jan Eivind Myhre and Ola Svein Stugu, eds., Historikerne som historie (Trondheim: Historisk institutt, 1996), 147-55.

42 Kaldal, Frå sosialhistorie til nyare kulturhistorie, 5.

43 See footnote 26.

44 Jan Eivind Myhre, 'Arbeid. Respekt. Glede. Knut Kjeldstadlis historiske forfatterskap, in Jardar Sørvoll, Trine Rogg Korsvik and Idar Helle, eds., Kollektive bestrebelser. Ei bok til Knut Kjeldstadli på 70-årsdagen (Oslo: Novus, 2018), 23-38. 


\section{Why Social History? The Question of Professionalisation}

Although the advent of social history obviously had its background in political and social change, I want to look more closely into another theme, that of professionalisation. What kind of professionalisation did historians during the decades of the 1960s and 1970s claim to bring with them, and how can it contribute to explain the rise of social history? I will talk about professionalisation in several steps, moving from the societal level, to historians and, finally, to social history.

The first meaning of 'professional' is in the sense that sociologists and others speak of 'professionalisation of society', 'professional occupations' and the like. The common criteria used are the interrelated factors of higher (theory based) education, expert knowledge, a certain control of the educational requirements by the practitioners themselves (including a gatekeeper function designed to limit access to the profession), public certification, competition within and between professions in fields of operation, extensive specialisation within the professions and (usually strong) organisations to advance all of these aims. ${ }^{45}$ One might also add an element of vocation, stemming partly from the professionals' commitment to science or scholarship, partly from their role as civil servants. Thus, the aim of the Norwegian academic was, to some extent, to serve society at large (a more European than American trait, perhaps), and to bring history to a wider public.

If we take historians specifically as our example, we can make the following claims. First, the tendency towards monopolising is weak; scholars in disciplines like archaeology, economics, sociology, anthropology or philology are 'permitted' to do professional (in the meaning of expert) history. The same applies to writers of historical works lacking formal qualifications like a PhD, as long as they meet what are considered professional standards. There is no public certification in the same sense as medicine or law, although a $\mathrm{PhD}$ in practice serves as one. Historians have no 'clients' or 'patients', although they have a readership and students. They have employers in a special sense (universities, etc.), but employers only in a more common sense of the word when doing commissioned history, which in the United States partly comes under the heading 'public history.' ${ }^{46}$ The bodies organising historians are hardly strong (this varies from one country to another), at least when it comes to the bodies' role as (trade) unions. On the other hand, historians are a very specialised bunch. As for the vocation element, professors of history in many countries are public servants, having an assignment from, and a duty towards, the public at large. German history professors in the nineteenth century have been described as a 'priesthood'. 47 'We cannot be satisfied with dry professional science', the prominent Norwegian historian Halvdan Koht wrote, 'we need a political spirit to keep history alive'. ${ }^{48}$

The professionalisation of society has been portrayed as crucial characteristic of modern societies, perhaps even the most important. ${ }^{49}$ There are, however, limiting forces and critical arguments towards professionalisation and professionals. These are inherent in the professions themselves but also stem from the outside world. ${ }^{50}$ First there is populism. By this, I mean that there is no specialist knowledge, academia is all common sense, an argument undermining the claim to expert knowledge. Applied to history, the past is for everybody to study and history for

\footnotetext{
45 Abbott defines the system of profession as 'expert division of knowledge', The System of Professions. An Essay on the Division of Expert Labor (Chicago: The University of Chicago Press, 1988).

${ }^{46}$ James M. Banner, Being a Historian. An Introduction to the Professional World of History (Cambridge: Cambridge University Press, 2012).

47 Wolfgang Weber, Priester der Klio. Historisch-sozialwissenschaftliche Studien zur Herkunft und Karriere deutscher Historiker und zur Geschichte der Geschichtswissenschaft 1800-1870 (Frankfurt: Peter Lang, 1985).

48 Quoted from Jan Eivind Myhre, 'A Strong Common Professional Identity. Professionalization and the Creation of a Discipline in Norwegian Historical Scholarship in the Twentieth Century', in Frank Meyer and Jan Eivind Myhre, eds., Nordic Historiography in the Twentieth Century (Oslo: Department of History, University of Oslo, 2000), 193.

49 Harold Perkin, The Rise of Professional Society. England since 1880 (London: Routledge 1989).

50 Ulf Torgersen, Profesjonssosiologi (Oslo: Universitetsforlaget, 1972).
} 
everybody to write. ${ }^{51}$ One may only think of the debates surrounding public history that have been, and still are, taking place in the United States and elsewhere. ${ }^{52}$ There are amateur historians but no amateur nuclear physicists or hobby surgeons. Then there is personalism. By this, I mean that professional work is dependent on the individual, and that there is no interpersonal guarantee of quality in job execution. Applied to history: when are you guaranteed to get a highquality product? To be sure, from a person known as a professional historian, one might expect a text of a certain quality, as one would expect from an officially chartered accountant. But then you have famous historians, not famous accountants.

The third limitation to professionalisation is, to use a neologism, innovatism. By this, I mean that it is difficult to be up to date with rapidly changing professional norms, which inevitably undermines the trust in expertise. Applied to history, this means that the constant outpouring of historical works makes it increasingly difficult to be up-to-date, even in restricted fields or subspecialties of history. At this point historians may turn to historiography; in trying to cover a field, a historian increasingly relies on historiographical surveys. Lastly, there is specialism, which is a strategy to overcome innovatism but threatens the unity of the professional field. All historians have met outsiders expecting in vain that they could answer historical questions. But the reality is that historians, like professional practitioners in other academic fields, inevitably become specialised.

What did the new social history contribute to this picture of professionalisation? Specialisation was certainly not new to history in the 1960s or 1970s. Even in a small country like Norway, there was economic history, local history, settlement history and rural history. Except for the first, the specialties were seldom named. This was the case also with so-called 'people's history'. But specialisation took on a new meaning around 1970. New sub-disciplines arose, some with conferences and seminars of their own. Norwegian historians started to call themselves 'historical demographers', 'labour historians', 'gender historians', 'business historians', 'urban historians' and so on. With specialisation came specialised terms (like Coale's index for demography), theories (class formation in social history) and methods (advanced quantification for economic history). This was surely a kind of professionalisation, mainly inspired by the social sciences (and later from anthropology and linguistics). The new social history was specialised and innovative; that is what made it professional. Its advanced theories and techniques made it inaccessible to some, even if this made it vulnerable to a populist critique. Perhaps (only perhaps) the acquisition of methods by many social historians made it less susceptible to the personalism critique.

A somewhat special case was the Swede Sven Lindqvist's book, Gräv der du står (literally 'Dig Where you Stand') from 1978. A Norwegian version was published in 1982. ${ }^{53}$ Tellingly, the Norwegian edition was subtitled researching your job and your locality, whereas the Swedish original was about the job only. The strong tradition of local history in Norway was thoroughly professionalised with the advent of social history in the 1970s, while the focus on the history of the work place gained momentum in the 1980s. It did not originate with Lindqvist's book but might have gained impetus from it.

At the same time, the norms for doing history changed. To understand this, we can use a theory about norms in historical scholarship, expounded by the Swedish historian Rolf Torstendahl (b. 1936), and on numerous occasions presented to Norwegian and international audiences. ${ }^{54}$ Torstendahl makes a distinction between what he calls 'minimum demands' and 'optimum norms' as characteristics of scholarly history. The minimum demands, well-known

51 Myhre, 'Historikeren og sosiologen'.

52 Ian Tyrell, Historians in Public. The Practice of American History, 1890-1970 (Chicago: The University of Chicago Press, 2005).

53 Sven Lindqvist, Grav der du står. Håndbok for dem som vil utforske arbeidsplassen og lokalmiljøet, Norwegian edition by Inger Bjørnhaug (Oslo: Tiden, 1982).

54 Rolf Torstendahl, The Rise and Propagation of Historical Professionalism (New York and London: Routledge, 2015). Torstendahl's many articles on professionalism are referred to in the book. 
from the heyday of source criticism from late nineteenth-century onwards (visible in methodological textbooks like Bernheim's in Germany, Langlois and Seignobos' in France and Erslev's in Scandinavia), comprise such factors as logical consistency, empirical reliability, internal coherence, objectivity. They rely heavily on factual accuracy and are empirically oriented. These minimum demands might be named 'old professionalism' (my term), but they are long-standing prerequisites for historical scholarship that persist today.

Optimum norms of scholarship, by contrast, include elements such as the research being 'important', 'fruitful', 'promising', 'theoretically sophisticated', 'relevant', 'rich in perspectives', 'pioneering' or 'original', referring to the norms of the wider community of scholars. ${ }^{55}$ I have called this 'the new professionalism' not only because the norms are different from the older version, but also because they frequently emanated from the world beyond the guild of historians, the tradition of source criticism being developed within the historical profession. We should note that the concept of relevance was crucial to the historians of the 1960s and 1970s.

We might say that the minimum demands and optimum norms correspond to the concepts of what is right and what is good, respectively. The newness of these optimum demands need not be exaggerated: there had already been the American tradition of progressive history, the French Annales history and the Norwegian tradition of writing people's history. What was new in the 1960s and 1970s, though, were the complicated techniques and methods and subtle theories, making some history writing less accessible to outsiders and even historians in other sub-fields. It is not always easy to decide which histories are 'good' or 'excellent' with optimum norms as our starting point. What does 'fruitful' or 'pioneering' really mean? Torstendahl has likened the differences between minimum demands and optimum norms to a ball game. ${ }^{56}$ The fundamental rules are written down, and the referee decides whether they are followed (minimum demands). But a good or excellent performance by a player or a team does not mean just playing according to the rules. An outstanding player moves gracefully, has a good overview of the situation, knows where his teammates are moving, has perfect control of the ball, passes and shoots precisely and works indefatigably. The analogy with historical scholarship is by no means perfect, but it conveys an idea of what is at stake. In reading historians about historians' works, it can be hard to pin down exactly what is commendable or deplorable about them. But we know it when we see it.

Did practitioners of the new social history comply with the standards of optimum norms, as outlined above? Their writings were often 'theoretically sophisticated' in terms of methods and theory. Some were 'pioneering' and 'original' in that they asked new questions and employed new sources. This may also have made their research 'rich in perspectives'. Were they also 'important' and 'relevant'? The new social historians certainly wanted to be because they wished to write the history of social groups that had been overlooked in history. On the other hand, we might ask whether technical jargon and intricate methods sometimes made their writings difficult to understand. This was part of the call to return to narrative frequently heard from the 1980s onwards. ${ }^{57}$

Beyond the Norwegian context, the values of the protagonists of the new social history were contested, for many reasons and in diverse ways. First, some historians held that they were at odds with older professional values, the ones mentioned as minimum demands above. Second, the new history was accused of being heavily politicised. This trait seems to have been more marked in the United States than elsewhere, perhaps because American politics and society were more conservative than in Western European countries. Novick writes that left-wing historians in the United States, because of their Marxist leanings, were just replacing one definition of

\footnotetext{
55 Some of these characterisations are mine.

56 Torstendahl, Rise and Propagation.

57 First introduced by Lawrence Stone in his 'The Revival of Narrative: Reflections on a New Old History', Past and Present (1979), 3-24.
} 
objectivity with another. ${ }^{58}$ Third, the new social history, with its social science tendencies and frequent use of quantitative methods, was criticised for making history dry and sterile. Fourth, the new history, with its breadth of approaches, topics and methods, was charged with fragmenting the discipline and encouraging relativism. Needless to say, these accusations could not be directed at one historian or a group of historians at the same time. For example, the two main tendencies in US new social history - the critical left and social science orientated history - were quite different when it came to both topics and methods. ${ }^{59}$

Still, the Norwegian case suggests that one of the key problems of the historiographical shift that accompanied the new social history was the threat of fragmentation of the whole history discipline into smaller units, a specialisation which I prefer to call professionalisation due to its increasing reliance on expert terms, theories and methods. ${ }^{60}$ This was, at least partly, the background for Sejersted's and Ohman-Nielsen's call for a renewed focus on political history. Another challenge to social history came from (the new) cultural history. In some ways cultural history seemed to increase the fragmentation of the discipline further, but its emphasis on meaning in history (rather than the structure of social historians) aimed at pulling history together. Still, it is clear that the various sub-disciplines that emerged out of the wave of new social history have not disappeared. Indeed, since the 1990s they have gradually entered more obviously into mainstream history. As the historical demographer Sølvi Sogner (1932-2017) noted in 1985: 'Clio when attired in her purely demographic draperies is no attractive lady to anyone but her most ardent admirers, who see her hidden charms in spite of an unprepossessing exterior' ${ }^{61}$

\section{Conclusion: Unity and Fragmentation of the Historical Profession}

Does increased specialisation and professionalisation in history mean that historians are a disparate lot, with no coherence, with little or no united purpose, no sense of community and therefore not a profession in the sociological sense? Does it make any sense to speak of historians this way? If history is not a profession, why speak about the limitations which reduce the professional elements? It is, of course, common to speak of the 'history profession'. This usually refers, not to some sociological meaning of the term, but to the expert knowledge which historians possess, the similar training they have gone through and their experience as community. Historians in various countries have often referred to their occupation as a 'guild', and still do (German 'Zunft', Norwegian 'laug', Swedish 'skrå), and their work as a 'craft' (French 'métier', Norwegian and Danish 'håndverk', Swedish 'handverk', German 'Handwerk'). ${ }^{62}$ Related terms include 'apprentice', 'journeyman' and, more seldom, 'master'. ${ }^{63}$ Of the numerous academic disciplines Becher studied in Britain and the United States, historians were the ones most likely to see themselves as belonging to the same fraternity, referring to the community of scholars. ${ }^{64}$

Thus, the distinction between the old and the new professionalism ought not to be stretched too far. Old professional norms still live with us. As for the new ones, the ideas of relevance and associated norms were not new in the 1960s, though they gained new currency with a more

58 Peter Novick, That Noble Dream. The 'Objectivity Question' and the American Historical Profession (Cambridge: Cambridge University Press, 1988), ch. 13.

59 Ellen Fitzpatrick, History's Memory. Writing America's Past, 1880-1980 (Cambridge, Mass.: Harvard University Press, 2002).

60 Myhre, Unification in the Age of Fragmentation.

61 Sølvi Sogner in a talk to the IUSSP 1985, according to Jan Eivind Myhre, 'I historiens hus er det mange rom. Noen hovedtrekk ved norsk historieforskning', in Jan Eivind Myhre, Mange veier til historien. Om historiefagets og histtorikernes historie (Oslo: Unipub, 2009), 82.

62 See Marc Bloch, The Historian's Craft (Manchester: Manchester University Press, 1954).

63 Thomas Etzemüller, 'How to Make a Historian. Problems in Writing Biographies of Historians', Storia della Storiografia (2008), 46-57.

64 Becher, Academic Tribes, 156. Tony Becher, Academic Tribes and Territories. Intellectual Enquiry and the Culture of Disciplines (Buckingham: The Society for Research into Higher Education \& Open University Press, 1989 ), 60. 
pluralistic history. Also, although 'relevance' may have come from outside the profession, this and similar values soon became norms internal to it, at least to some extent, varying from country to country. From a professionalisation point of view, a common factor between the two would normally be that the norms are decided within the community (or part of it) of history scholars, internal to the history profession, so to speak. Norm-sets, minimum demands and optimum norms all serve to keep the community together or, indeed, to create the community itself. For a historian to obtain recognition from the community, at least some of the norms must be followed. The norms of the community may assist in delimiting historians from other scholarly disciplines, but also in marking a boundary between themselves and amateur historians.

It is perhaps in the question of the existence of a community of historians that the two meanings of professionalism meet. The challenges facing history in Norway as a profession in the second half of the twentieth and the early twenty-first centuries concern the variety of optimum norms employed. Examples of this are the Marxist approach to history (focusing on social groups and class struggle), the comprehensive approach of a Braudel (distinguishing between three different time levels), historical demography and social history in its many new versions (taking inspiration from the social sciences, like the German Geschichte und Gesellschaft 'school'). All of them, and more, were part of the Norwegian movement of social history from 1970 onwards. But, as it turned out, they did not threaten the coherence of the academic Norwegian history community. A version of people's history was already established and a mutual respect for the many varieties of history was present. Taking the gains of social history with them, and adding some aspects of the new cultural history, Norwegian historians in the twenty-first century seem to have reached a new mainstream history. 